\title{
Cognitive-Semantic Analysis of Linguistic Objectifications of Possessive Situations in Russian, English, German
}

\author{
Irina Palashevskaya, Vladimir Leontiev, Elizaveta Stepanova, Yulia Kulichenko, and Elena Kurchenkova* \\ Philological Sciences, Department of Foreign Language Communication, 400062, University A., 100, Russia
}

\begin{abstract}
In this article, possessivity is considered to be a linguistic way of integrating an object (thing) into a relation, connected, first of all, with the idea of owning, wealth and property. Owning a thing is one of the most important concepts regulating social relations. The grounds on which a thing belongs to its holder, in various legal and cultural traditions, often serve as justification of the material advantage and the manifestation of privileges. The relations of possessivity aimed at holding the object in the subject's sphere are proposed to be constructed in the form of cognitive models, the content of which is the multidirectional process, which is reflected in the semantics of linguistic units and has lingua-cultural specifics. The article proposes cognitive models of possessive relations and describes the language tools representing the structural components of the constructed cognitive models. The relevance of various characteristics to the compared languages and cultures based on the comprehensive analysis of verbalization of the structural components of these models has been identified in this work.
\end{abstract}

\section{Introduction}

Possessivity, being a social phenomenon expressed by language means, is primary associated with ownership of wealth, including individually owned items (such as land, houses) or financial assets (fortune, capital), as well as such aspects of human wellbeing as health, dignity, respect and reputation, etc. The attitudes towards the ways of using wealth (varying from losing, flaunting it, making lavish spending on pleasures and almsgiving, squandering it in the most demonstrative way to manifest the status inequality or on the contrary thrift and sound use of it up to emphatic modesty and excessive parsimony) differ among classes and cultures and act as a source of behavioral models encouraged or condemned and mocked at in ethnic literature traditions. A possessed item, performing a sociorepresentative function, can act as the bearer of metacommunicative messages about its holder (owner) in his/her tie with it and his/her way to use this item as wealth, directed to its proper keeping, saving and accumulating, or squandering and wasting.

\subsection{The concept of possessivity in linguistics}

In linguistics, the description of possessivity is presented in the works by A.V. Bondarko [1], B. Heine [2], M. V. Milovanova [3], L. N. Golovacheva [4], and others. Relations between two entities lie at the core of the notion of possessivity. The structure of these relations, as stated by M.V. Milovanova, includes the following points: A (object) is the property (wealth) of $\mathrm{B}$ (subject); 2) $\mathrm{A}$ is an integral part of $\mathrm{B}$; 3) $\mathrm{A}$ is a sign of $\mathrm{B}$; 4) $\mathrm{A}$ is included in the sphere of interests of $\mathrm{B}$ in a certain sense [3]. In this article we focus our attention on the first manifestation of possessivity when some object is the property of some subject.

The concept possession exists in the form of ideas shared by representatives of culture in the values that are embodied in a number of expectations of the behavior of the subjectpossessor in relation to the object of the possessive relations. The representation of this behavior in the language is largely due to national and cultural features reflecting the worldview of cultural representatives. It seems promising to compare the semantic structure of the linguistic means with the application of a comparative approach [5].

The study of cultural patterns of behavior seems to be impossible without the analysis of their value-estimation component. The estimates are expressed in reactions to people's actions, while typical reactions are formulated in the form of stable expressions. They are also expressed in the concentrated form in the meanings of words. Cultural values manifest themselves in estimation of the behavior of people. The estimation assumes the presence of the estimation scale, which is a dynamic gradual sequence of positive, negative and neutral values. A neutral zone is an area where positive and negative signs are balanced. Negative estimates of a certain ratio of the subject-possessor to the object are most pronounced in words of a particular pejorative value, such as miser or skinflint. Positive estimations are included in words-melioratives, such as thrifty.

Relationships with the object of possession include possessive situations concerning keeping it, proper or improper saving, amassing of wealth or its reducing, dissipating and squandering. 
The mentioned possessive situations can be represented in the form of the following cognitive models: "subjectpossessor", "possessed object", "subject-object relations of possession". These models, in turn, include sub-models and structural qualifiers specifying the representations of a typical subject, object, and the process of possession [6].

In this article we dwell on the description of the subject of possessive relations, his/her nominees, explicating the encouraged or condemned in culture ways of using an object as wealth.

\section{Results and Discussion}

The material of the study includes the fiction texts of Russian, English authors, such as N.V. Gogol, F.M. Dostoevsky, D.N. Mamin-Sibiryak, Sh. Bronte. In addition, the data of etymological, explanatory modern dictionaries of Russian, English and German languages have been used.

\subsection{The cognitive model "subject-keeper"}

The cognitive model of the "subject-possessor" includes the following sub-models (SM): SM1 "the subject-keeper", SM2 "the subject-accumulator", SM3 "the subject-spender". SM1 "the subject-keeper" consists of the following structural qualifiers (SQ): 1. "Subject-keeper in general (neutral)"; 2. "The keeper due to the nature of his/her character": thrifty, economical, practical, prudent; 3. "The keeper due to professional activity": a) in the militarized sphere, b) in the economic sphere, d) in the cultural sphere; 4. "The keeper by virtue of moral motives"; 5. "The keeper in religious mythology".

The subject is an active party of property relations; he/she possesses, stores, increases or loses the property object. SQ "subject-keeper in general (neutral)" in the framework of SM1 "subject preserving smth" in the Russian language is represented by the language unit custodian. Old Russian хоронити goes back to choronity from chorna 'protection' [7], thus, it can be said that this language unit nominates the subject who guards and protects the object from danger: Наконец, последняя дочь, оставшаяся с ним в доме, умерла, и старик очутился один сторожем, хранителем и владельием своих богатств - Finally, the last daughter staying with him in the house, died, and the old man found himself as the only guard, the keeper and the owner of his wealth [8].

The key language unit designating the subject-keeper in general (neutral) in English is the noun keeper. In the semantics of the unit, the sign of possession is more explicitly presented, as it is evidenced by etymological data: the verb to keep goes back to the Old English verb cepan and has the following meanings: to seize 'to own something, to take possession; grab', to hold 'have or keep, hold something in your possession', as well as to observe 'look at, watch'. The subject, characterized by the lexical unit keeper, has got the certain professional duties, is the proprietor, the owner of something: shop-keeper, inn-keeper [9].

In German, the subject-keeper is characterized by a number of units-sogiponims, i.e. there is a detailed qualification of the subject-guardian in general: the language unit-dominant Hüter (Behüter), the derivative of the Middle High German huote 'protection, care'; Erhalter 'the keeper of his/her financial situation and family', 'the keeper of mental well-being', Bewahrer and Verwahrer 'the custodian for future use'.

The analysis of the representation of SQ "due to the character traits" expressing the subject that can be described as economical, practical, hard-headed, prudent, thrifty in the compared languages shows that the Russian adjective бережливый (thrifty, economical) characterizes a person that tries to keep something and spend less, he/she does not want to lose his/her property: ...бережлива старушка $и$ салопу суждено пролежать долго в распоротом виде ... the old woman is economical and the coat will be left unstitched [8].

In the semantic structure of the English words economical and thrifty and their German equivalents sparsam, wirtschaftlich, umsichtig the emphasis is on the economy, prudence and desire for making profit and avoiding waste: ... and his father at least liked money. He, too, has always been called careful [10]; German: eine sparsame Hausfrau.

SQ "the keeper due to the professional activity" is widely represented in all languages under consideration. Within this microgroup the main features of the subject are keeping, protecting, and watching the object. While qualifying the subject as a keeper of the property and order we can see the similarity in the languages but there is a detailed structuring of this type of subject in the German language.

We have identified the other structure qualifier as "the subject-keeper due to the morality". The object can be tangible (e.g. property) or less tangible, abstract (e.g. life, health). This type of subject has legal right to protect the other subjects and their property (e.g. Russian опекун, попечитель; English custodian, guardian; German Vormund (lit.: 'in front of the mouth'); Treuhänder (lit.: 'loyal supporter').

The next SQ within the submodel "subject-keeper" is SQ "in the religious mythology". First of all, it is a guardian angel (Russian ангел-хранитель, German Schutzengel, Schutzheiliger).

In general, SM 1 "the subject-keeper" can be described as protecting, watching, observing and represented by common words and professional terms.

\subsection{The cognitive model "subject-accumulator"}

SM 2 "the subject-accumulator" includes the following structure qualifiers as: 1) "due to the character traits": a) penny-pincher; b) mean and stingy; c) greedy; 2) "at others' expense": a) plundering one's property; b) inclined to cheat and fraud; c) mercenary-minded and griping.

SQ "due to the character traits" is presented by three microgroups. The subject described as a penny-pincher has a negative connotation in all languages under consideration. The basis of this image is formed by little negligible things like coins (e.g. копеечник, pепny-pitcher), hair (e.g. hairsplitter), and even "small" soul (e.g. Krämerseele (lit.: 'the 
soul of a small grocer'). The stereotypes are also used (e.g. sly fox-Pfennigfuchser).

Having analysed the semantic structure of the words describing a mean and stingy subject, we can draw the conclusion that this kind of a person is not only economical, he is not willing to give or share money. His aim is to spend as less as possible. The Russian words скупеи and скряга are formed with the help of the suffix -яza that comes from the unit скра 'a stone, rock' [11]. Thus, the mean person is associated with the stone: Такой скряга, какого вообразить трудно; Скрягу Плюшкина не знаешь, того, что плохо кормит людей? - He is incredibly mean; Don't you know the mean Plyushkin who feeds people badly? [8].

A very miserly person can be characterized by another Russian word скупердяй. It is a colloquialism that has a very strong negative connotation. There are also associations with a wealthy peasant (Rus. кулак) and the mythical creature кощей from the Russian fairy-tales.

In the English language a mean subject spending as little money as possible is described by the words miner, niggard: "I could not spare the money on my account". "Little niggard!" [10]; and is metaphorized by the colloquialism skinflint that literally means 'flint, stone from the skin'. There are many German words characterizing a mean person that never gives anything (money, things) or does it in a very small quantity: Geizhals (lit. 'mean and greedy neck'), Geizkragen (lit.: 'mean and greedy collar'), the noun Geiz comes from Old High German 'greed' [12]. This type of subject can also be expressed by rude words, invectives: Geizhammel (lit.: 'mean and greedy sheep'), Geizknochen (lit.: 'mean and greedy bone') with a very strong negative connotations.

In the semantic structure of the greedy subject there is an emphasis on the desire of the person addicted to money to spend them as little as possible: ... жаднюший до денег, $a$ тут сами деньги приходили на дом: возьми ради Христа [13] - He is addicted to money and they came to him themselves: take us for Christ's sake!

This type of greedy subject is represented by the Russian colloquialism жадина, scornful words сквальга and скалдырник, as well as an abusive word скареда.

The extremely greedy subject whose dominant desire is to hoard his money is characterized by a colloquialism скопидом and words formed on the basis of association: плюшкин, полушечник. In the English language there are different words describing the subject who is unwilling to spend or give money and inclined to hoard it: greedy person, avaricious grasping man: ...that my father was an avaricious grasping man [10], stingy person tight-fisted, miser, hoarder. In the German language the greedy subject is represented by metaphors Geizkragen and Filz (lit.: 'felt') characterizing a rude and impolite person; Nimmersatt - a subject addicted to food, always hungry, Knicker, Knauser, Pfennigfuchser.

Thus, in the Russian language there is a more detailed qualification of the economical and greedy subject. A stingy person is characterized by his/her desire to lessen his/her expenses and increase his/her property, amass his wealth as a result; a greedy person is willing to save and multiply his/her profit and a penny-pincher has something in common with both of them. The following example illustrates the gradation of the characterisation of a very greedy person in the Russian language: Пьяная расточительность, когда Мыльников бахвалился и сорил деньгами, сменялась трезвой скупостью и даже скаредностью - Drunken lavishness when Mylnikov was boasting and throwing his money around transformed into sober stinginess [14].

There is no such detailed description of a greedy person in the English and German languages.

The analysis of SQ "at others' expense" shows that there is a concept of a sly, greedy and living off others' subject in all languages under consideration. This qualifier is represented by some microgroups. The first group describes the subject plundering and stealing one's property. First of all, it is a person that steals money from other people's pockets, especially in crowded places. This type of subject is described by the English words pickpocket, thief, petty thief and their German and Russian equivalents Dieb / вop 'thief' and Taschendieb / вор-карманник 'pickpocket': ... что если б ему удалось теперь доказать, что Софья Семеновна - воровка... - What if he were able to prove that Sofja Semyonovna is a thief [13].

The second group characterizes a subject inclined to cheat and fraud. The Russian colloquialism жулик (it comes from the verb жулить 'to embezzle'), мошенник, спекулянт, фальшивомонетчик, шулер (it comes from the Polish language of XIX century: szuler 'gambler').

The immoral subject living at others' expense is described by the following English words: cheat, fraud, parasite, spiv, deceiver; rogue, scoundrel, rascal, swindler (comes from the German noun Schwindler), trickster, (card)-sharper, rook.

This type of subject is characterized by the German words Schurke 'rogue', а также "kleiner Gauner", Parasit, Lump (scoundrel), this noun comes from Middle High German lumpe 'rags' [12]; Gauner, Spitzbube, Bauernfänger, Falschmünzer 'forger', Spekulant, Schieber, Betrüger, Hochstapler, Falschspieler ('card-sharper').

Thus, theft, greed and money obsession have negative connotation in all lingua-cultures under our consideration.

The next microgroup includes units nominating a mercenary person, greedy for acquisition, namely, a type of subject that seeks profit at the expense of others (for example, to borrow and not return). In Russian, this type of subject is expressed by the lexical unit of the bookish style стяжатель (money grubber): Стяжатель по натуре Кишкин тащил в свою каморку...; И та дура... невольно соглашалась Марковна, в которой шевельнулся инстинкт бабьего стяжсательства - вот нам и делить нечего... - The money-grubber by nature Kishkin dragged to his cubby-hole...; And that stupid woman - involuntarily agreed Markovna, in which the instinct of the woman's money-making moved - here we have nothing to share...[14].

In English, this type of subject is nominated by the word combinations: grasping person, person on the make, money grubber, and also by the lexical unit skinflint. In German linguaculture, the self-interested subject is expressed in the semantics of the following word combinations: habgieriger (habsuechtiger, gewinnsuechtiger) Mensch, Geizhals. 
Analysis of the representation of SM2 "the subjectaccumulator" shows that the characteristics of the subject excessively thrifty, greedy are the most fully represented in the Russian language, and all units nominating it have sufficient frequency.

\subsection{The cognitive model "subject-spender"}

SM3 "subject-spender" includes the following structural qualifiers: 1 . due to circumstances; 2 . due to the character traits: a) disinterestedly, b) carelessly, irresponsibly, c) due to the weakness of character.

SQ "due to circumstances" is represented by units nominating the subject, reducing the size of property in large or small quantities: Привалов не различал своего от имущества жены и много растратил - Privalov did not distinguish his wife's property from his own one and wasted a lot [14].

The native speakers of the Russian language call such a subject with disapproval as pacmpaтчик (embezzler). Semantic complex of this lexical unit implies actualization of the meaning of waste of personal money, as well as money entrusted to the subject. In English and German, only the meaning of subject who spends other's money that was in the possession of the subject and, of course, in his/her favor is revealed. In English, such subject is nominated by the noun embezzler, from the Anglo-French language embesiler 'to steal', peculator, in German -Veruntreuer (lit.: 'a man who cannot be trusted') 'embezzler, plunderer': sie haben die Gelder ihres, Bruders veruntreut, Unterschlagungstäter; Defraudant [15].

The next SQ "due to the character traits" is represented by units that nominate a subject who reduces property disinterestedly, carelessly, criminally: due to the weakness of character. In the Russian language, the feature of the subject that does not seek personal gain, benefit is actualized in the semantics of the units characterizing the selfless person. To characterize such a subject, neutral or bookish vocabulary is used: бескорыстник; бессребреник (unselfish person). In English and German, lexical units include a connotation with an evaluation component in their meaning. In English, the subject is associated with a person who is not influenced by his feelings, sensations, prejudices or interests; he/she is a disinterested person. In the German language - with a person 'not useful for himself': uneigennuetziger (selbstloser) Mensch. Semantic analysis of units indicates that the speakers of the Russian language positively assess the subject as disinterested; the speakers of English and German - as a rule, negatively.

The subject who is spending carelessly, in Russian is called транжира (spender), who spends criminally, recklessly. There is a bookish lexical unit расточитель (wasteful person) and colloquial word моm (spend-all): $A$, говорит, племянника не знаю; может он мот - I, he says, do not know my nephew; maybe he is a spend-all [8].

The subject is characterized as not restraining himself by the arguments of reason, prudence. In English, this subject is described by the lexical unit squanderer, person who spends recklessly, in large quantities, spendthrift, waster - the noun comes from Ancient French unit guaster 'to destroy, spoil, prodigal; dissipater'. This type of subject in German is represented by lexical units that etymologically directly indicate this meaning, for example: Vergeuder. Middle High German verbgiuden has the following meaning: 'boasting, living wastefully' [12]; Verschwender comes from the Upper-High German prefixed verb bugverswenden 'to destroy, absorb (food)' [12], as well as Durchbringer, Verschleuderer, Verplemper. The word-forming components, prefixes durch-, ver- mean the expenditure or loss of something by the subject.

The subject, who reduces property due to weakness of character, has similar characteristics in the analyzed languages. The quality of the subject's weakness is directly related to the carelessness and recklessness that manifests itself in the behavior of the subject. The difference in characteristics is observed only in the expression of connotations: прожигатель жизни (lit.: burner of life) - in Russian it literally means 'who burns himself', in English such subject is associated with a quick living: fastliver, and also heavily drinking: harddrinker, in German - with the life of a person who burns life for pleasures: Lebemann.

\section{Conclusion}

Thus, the representation of possessive situations in the language is largely due to the national and cultural characteristics of the worldview. The situations identified by us (saving, accumulating and squandering of wealth) are considered in the lingua-cultural aspect from the standpoint of cognitive modeling. These situations can be represented in the form of the following cognitive models: "subjectpossessor", "possessed object", "subject-object relations of possessing", which, in turn, include sub-models and structural qualifiers that specify them, the patterns of representation of which are reflected in the semantic of linguistic units.

The cognitive model of "subject-possessor" includes sub-models of: "subject-keeper", "subject-accumulator", "subject-spender". The greatest qualification in the comparative lingua-cultures is obtained by the subjectaccumulator, the smallest - the subject-spender. While representation of the established structural qualifiers, the following characteristics of the subject are relevant: for the Russian lingua-culture - subject-protector, for English subject- owner, for German - the subject actually preserving an object in the personal sphere. In the Russian language, unlike in English and German, a subject that spends his/her wealth on almsgiving or reduces property as a result of its disinterested transfer to another person can receive a positive evaluation.

\section{References}

1. A.V. Bondarko, Theory of meaning in the system of functional grammar: On the material of the Russian language (Languages of Slavic culture, Moscow, 2002)

2. B. Heine, Possession. Cognitive sources, forces and grammaticalization (Cambridge University Press, Cambridge, 2006) 
3. M. V. Milovanova, Category of possessivity in Russian and German languages in lingvocultural view (Volgograd scientific publishing house, Volgograd, 2007)

4. L. N. Golovacheva, Category of possessivity in Slavic and Balkan languages, 45-111 (Nauka, Moscow, 1989)

5. A.V. Arzhanovskaya Y.N., Kulichenko O.Y., Popova Y.I., Linkova E.M. Korolevskaya, XLing. J. 10, 78-84 (2017)

6. E. D. Stepanova, Cognitive modelling of property preservation relations in Russian, English, German linguocultures (Volgograd, 2013)

7. M. Fasmer, Etymological dictionary of the Russian language (Astrel, Moscow, 2009)

8. N. V. Gogol, The Dead Souls: A Poem (Azbuka, Moscow, 2014)

9. Oxford Advanced Learner's Dictionary (OLD) (Oxford University Press, Oxford, 2015)

10. Ch. Bronte, Jane Eyre (Penguin Books Ltd., England, London, 2006)

11. N. M. Shansky, Phraseology of the Modern Russian Language (Editorial URSS Librocom, Moscow, 2010)

12. Duden Etymologie Herkunftswoerterbuch der deutschen Sprache (DHW) 7 (Dudenverlag, Berlin, 2001)

13. F. M. Dostoyevsky, Crime and Punishment (ExmoPress, Moscow, 2016)

14. D. N. Mamin-Sibiryak, Privalov's millions. Gold (Russia, Moscow, 1989)

15. Duden Bedeutungswoerterbuch (DBW) 10 (Dudenverlag, Berlin, 1989). 